\title{
The Influence of Electrode Configuration on the Performance of Electrode- Supported Solid Oxide Fuel Cells
}

B.W. Chung, A.Q. Pham, J.J. Haslam, R.S. Glass

This article was submitted to $198^{\text {th }}$ Meeting of the Electrochemical Society, Phoenix, AZ, October 22-27, 2000

U.S. Department of Energy

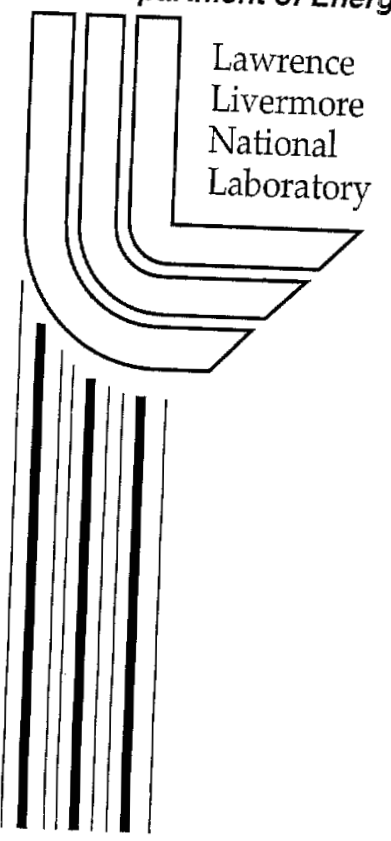

May 19, 2000 


\section{DISCLAIMER}

This document was prepared as an account of work sponsored by an agency of the United States Government. Neither the United States Government nor the University of California nor any of their employees, makes any warranty, express or implied, or assumes any legal liability or responsibility for the accuracy, completeness, or usefulness of any information, apparatus, product, or process disclosed, or represents that its use would not infringe privately owned rights. Reference herein to any specific commercial product, process, or service by trade name, trademark, manufacturer, or otherwise, does not necessarily constitute or imply its endorsement, recommendation, or favoring by the United States Government or the University of California. The views and opinions of authors expressed herein do not necessarily state or reflect those of the United States Government or the University of California, and shall not be used for advertising or product endorsement purposes.

This is a preprint of a paper intended for publication in a journal or proceedings. Since changes may be made before publication, this preprint is made available with the understanding that it will not be cited or reproduced without the permission of the author.

This work was performed under the auspices of the United States Department of Energy by the University of California, Lawrence Livermore National Laboratory under contract No. W-7405-Eng-48.

This report has been reproduced directly from the best available copy.

Available electronically at http://www.doc.gov/bridge

Available for a processing fee to U.S. Department of Energy

And its contractors in paper from

U.S. Department of Energy

Office of Scientific and Technical Information

P.O. Box 62

Oak Ridge, TN 37831-0062

Telephone: (865) 576-8401

Facsimile: (865) 576-5728

E-mail: reports@adonis.osti.gov

Available for the sale to the public from

U.S. Department of Commerce

National Technical Information Service

5285 Port Royal Road

Springfield, VA 22161

Telephone: (800) 553-6847

Facsimile: (703) 605-6900

E-mail: orders@ntis.fedworld.gov

Online ordering: http://www.ntis.gov/ordering.htm

OR

Lawrence Livermore National Laboratory

Technical Information Department's Digital Library

http://www.llnl.gov/tid/Library.html 
The Influence of Electrode Configuration on the Performance of Electrode-Supported Solid Oxide Fuel Cells

Brandon W. Chung, Ai-Quoc Pham,, Jeffery J. Haslam and Robert S. Glass

\section{University of California, Lawrence Livermore National Laboratory \\ Chemistry and Materials Science \\ P.O. Box 808, L-350, Livermore CA 94551}

Unlike self-supported electrolyte cells, the electrodesupported cells always have one electrode (the support electrode) larger than the other electrode. The conventional approach is then to normalize the power output to the small electrode area. In some cases, the power density is normalized to the area of the current collector, which is even smaller than the area of the small electrode [1]. However, it is unclear whether the current density and the power density are truly independent of the cathode/anode size ratio as is implicitly assumed in the above normalization practices. The aim of this study is to investigate the change in normalized power density with the different electrode area ratios as well as the effect of the current collector area.

We fabricated NiO-YSZ anode supported fuel cell with yttria-stablized zirconia (YSZ) as thin film electrolyte and $(\mathrm{La}, \mathrm{Sr}) \mathrm{MnO}_{3}-\mathrm{YSZ}$ as the composite cathode. Cells with asymmetric and symmetric electrode geometry were prepared by depositing the cathode with different areas. Two cases were studied: poor cathode/good anode cells and good cathode/ good anode cells. The poor cathodes and the good cathodes were deposited using the screen-printing technique and the Colloidal Spray Deposition process respectively (2). The symmetric cell with a screen-printed cathode had a power density of $0.45 \mathrm{~W} / \mathrm{cm}^{2}$ at $800^{\circ} \mathrm{C}$ in air/ $/ \mathrm{H} 2$ as shown in figure 1 . However, asymmetric cells having the same cathode material but with a significantly smaller area than the anode exhibited much higher normalized power density (figure 2). Therefore, decreasing the cathode/anode area ratio results in an increase in power density, which can be several times higher than that measured for symmetric cells. The increase of the power density with decreasing area ratio was attributed to the spreading of the current over the entire anode, which minimizes the anode polarization contribution for asymmetric cell testings. Since the fuel cell stack has essentially symmetric cells, the power density determined using asymmetric cells does not reflect stack power density. For the CSD deposited cathode, the performance improved significantly and resulted in symmetric cell power density of $820 \mathrm{~mW} / \mathrm{cm}^{2}$. The effect of the area ratio on the normalized power density is less pronounced.

Using a current collector with smaller area than the cathode (screen-printed) area contributes an extra enhancement that leads to apparently higher power density of $1.2 \mathrm{~W} / \mathrm{cm}^{2}$ as shown in figure 3 . In this configuration, the normalization is done considering the area of the current collector. This normalization approach is based on the assumption that the conduction in the cathode outside of the current collector is negligible. The power density corresponding to this configuration is higher than that of the cell having the same area ratio in figure 2. This apparent difference in the performance clearly indicates that the cathode region that does not have the current collector does contribute to the current conduction.

In conclusion, we have demonstrated that large change in power density of a single cell could occur just using different electrode geometry and normalization procedures. Power density measurement using asymmetric cells does not reflect the true performance since this configuration minimizes the contribution of the support electrode polarization to the total cell voltage.

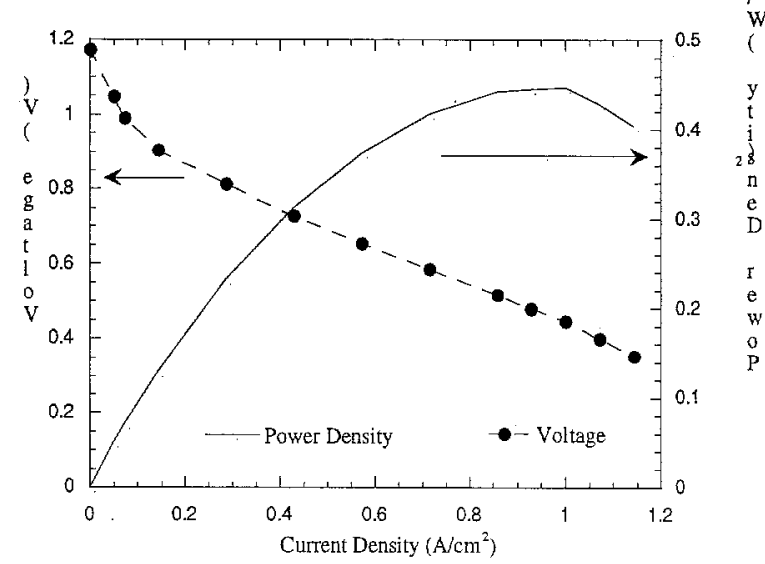

Figure 1. Symmetric fuel cell performance at $800^{\circ} \mathrm{C}$

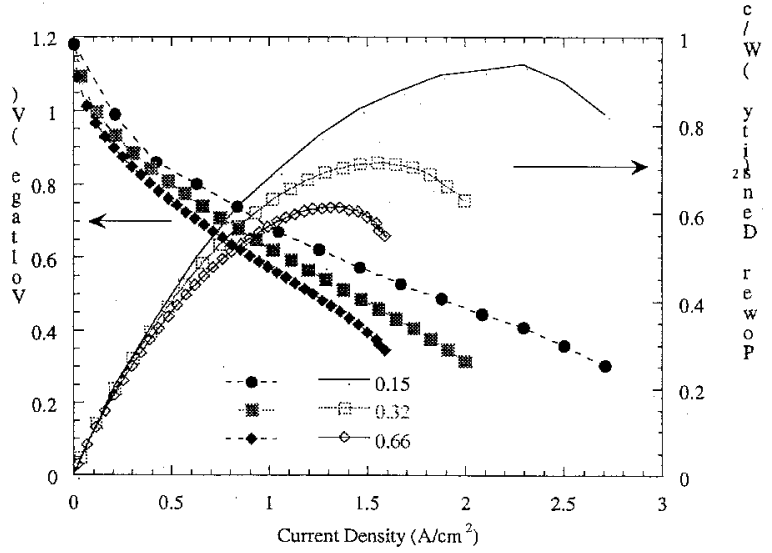

Figure 2. Asymmetric fuel cells with cathode-current collector/anode area ratios of $0.15,0.32$, and 0.66 at $800^{\circ} \mathrm{C}$ 


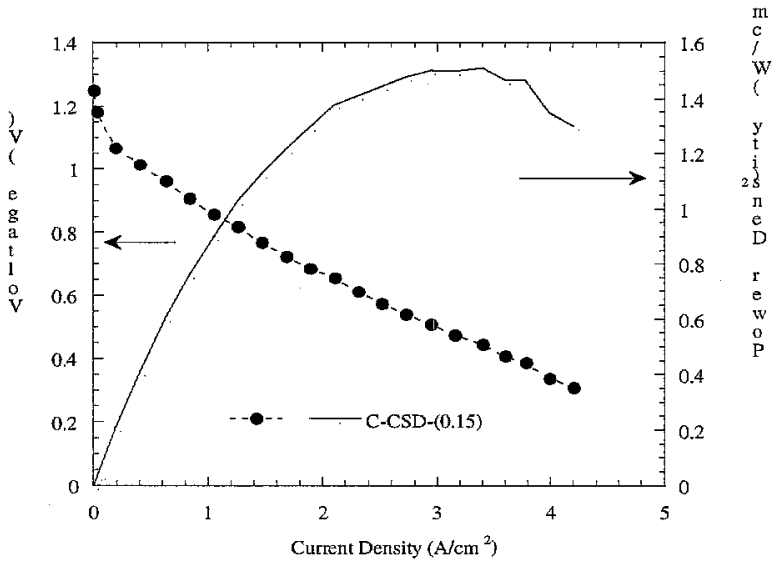

Figure 3. Asymmetric cell with a current collector area smaller than the cathode (screen-printed) area at $800^{\circ} \mathrm{C}$ Reference

[1] S. de Souza, S.J. Visco, and L.C. De Jonghe, Solid State Ionics, 98 (1997) 57.

[2] A. Q. Pham, T. H. Lee, and R. S. Glass, in: S. C. Singhal and M. Dokiya (Ed.), Proceedings of the $6^{\text {th }}$ International Symposium on Solid Oxide Fuel Cells. The Electrochem. Soc., Pennington, NJ. USA (1999) p. 172.

Work performed under auspices of US DOE by LLNL, contract W-7405-Eng-48. 